\section{Paul Onanuga}

Federal University Oye-Ekiti, Nigeria

Rotimi Taiwo
2020, Vol. 17 (2), 61-82(284)

revije.ff.uni-lj.si/elope

https://doi.org/10.4312/elope.17.2.61-82

UDC: 81 '42:[343.72:004.738.5]

Obafemi Awolowo University, Ile-Ife, Nigeria

\title{
Discursive Features of Nigerian Online Ponzi Schemes' Narratives
}

\begin{abstract}
Although Ponzi schemes have existed since the 1800s, contemporary financial challenges have rejuvenated them while the Internet has enhanced their proliferation, particularly in developing countries. The present study analyses select discursive features for digital deception in Nigerian online Ponzi schemes. We identify the use of stance and linguistic engagement, formulaic expressions and politeness strategies, narrativity, naming, and lexical range as techniques used by scheme creators. These linguistic and discursive choices are wielded as tools to attract customers and, ultimately, to deceive. The overt propagation of financial gains has underlying ideological implications, as it projects a sense of communality and encourages financial leverage which are in turn exploited to con unsuspecting - often greedy - subscribers. We conclude that language use in Ponzi schemes is intentionally crafted to appeal to diverse individual sentiments, particularly within developing economies where poverty is widespread and people seek to make money through any means in order to survive.
\end{abstract}

Keywords: Ponzi schemes, digital deception, internet scam, discourse analysis, linguistic strategies

\section{Diskurzivne značilnosti naracije v nigerijskih spletnih Ponzijevih shemah}

\section{POVZETEK}

Čeprav Ponzijeve sheme obstajajo že od 19. stoletja, so jih sodobni finančni izzivi pomladili, internet pa je povečal njihovo širjenje zlasti v državah v razvoju. Ta študija analizira izbrane diskurzivne značilnosti za digitalno zavajanje v nigerijskih spletnih Ponzijevih shemah. Kot tehnike, ki jih uporabljajo ustvarjalci shem, lahko prepoznamo rabo stališča in jezikovne zavzetosti, formularnih izrazov in strategij vljudnosti, narativnosti, poimenovanja in leksikalnega obsega. Te jezikovne in diskurzivne izbire se uporabljajo kot orodja za privabljanje pokroviteljev in za zavajanje. Odkrito razširjanje finančnih dobičkov ima dejanske ideološke posledice, saj projicira občutek skupnosti in spodbuja finančni vpliv, ki se nato izkorišča za nič hudega sluteče, pogosto pohlepne naročnike. Sklepamo, da je uporaba jezika v Ponzijevih shemah namerno zasnovana tako, da vpliva na različna čustva posameznikov, zlasti v državah $\mathrm{v}$ razvoju, kjer je razširjena revščina in ljudje skušajo zaslužiti na kakršen koli način, da bi preživeli.

Ključne besede: Ponzijeve sheme, digitalna prevara, spletna goljufija, diskurzna analiza, jezikovne strategije 


\section{Introduction}

Around the middle of 2016 in Nigeria, there was a sudden rise in testimonies about a 'legitimate' money-making venture which promised $30 \%$ for all financial investments lodged. Suddenly in the consciousness of a national audience, millions of desperate Nigerians, evidently encouraged by the downturn in the nation's economic fortunes, joined the bandwagon. The frenzy was generated by MMM, short for Mavrodi Mundial Moneybox, a Ponzi scheme of Russian roots which had operations in several other countries (Hess and Soltes 2018). In spite of warnings from the Nigerian government, the Central Bank of Nigeria (CBN) and the Nigeria Deposit Insurance Corporation (NDIC), many people decided to join the Ponzi scheme. However, when the bubble burst upon the sudden freezing of mavros - a virtual currency created by the MMM managers - prior to the December 2016 Christmas festivities and consequent insolvency of MMM, it was estimated that about three million Nigerians lost billions of naira, the Nigerian currency. MMM Nigeria was created in November 2015, spent a few months growing its subscriber base, hit the heights and lasted for a little over a year in total - the brief duration of its existence being customary of Ponzi schemes. Although it made a comeback in the middle of 2016, it never regained its former popularity. Since its collapse, several schemes have leveraged the publicity which MMM generated. The rate at which these schemes mushroomed daily, enticing subscribers with unrealistic and unjustifiable returns, coupled with the way in which Nigerians thronged to them, justify the present study. Luukkonen $(2014,5)$ underlines the necessity of exploring Ponzi schemes by saying:

Ponzi and pyramid schemes are a topical, complicated phenomenon that can be studied from several viewpoints: their internal structures and impact on surrounding economy can be remarkable, not to mention their impact on individual lives; they arouse questions of ethics and justification in regards to prevailing social problems; and they can also be fascinating examples on persuasion, deception and manipulation.

Ho et al. $(2016,394)$ also claim that "linguistic features can provide crucial cues to detect deception". The present study examines how linguistic choices perform interpersonal, attitudinal and ideological functions on Nigerian Ponzi scheme webpages. Specifically, attention is paid to lexical choice, stance and linguistic engagement, commissives, politeness strategies, and narrativity. We identify these as language choices for persuasive purposes in the self-presentation on the webpages of selected Nigerian Ponzi schemes. The features are studied particularly with a view towards how these linguistic strategies resonate with the interrelated themes of persuasion and deception of potential victims.

\section{Digital Marketing and Digital Deception}

The availability of the internet as well as the integration of technology into business has had far-reaching consequences. The resultant efficiency and the inexpensive ways of connecting businesses and disseminating information to consumers have ensured that more businesses rely on these platforms. According to Onanuga (2017), these transactions are aided by media like smartphones, interactive channels, banner ads, digital outdoor marketing, and social networking platforms. A critical feature of digital marketing which enhances public appeal is its multimodal nature (accommodation of text, images, music, video, etc.), which 
is completely different from traditional communication platforms (Tsikerdekis and Zeadally 2014). However, digital marketing has also been blighted by increasingly widespread and fraudulent practices. These digital deceptive engagements are encouraged by the relative anonymity which the digital space affords users.

Digital deception is occasioned by the perpetration of unwholesome practices online. Hancock $(2007,289)$ defines digital deception as "the intentional control of information in a technologically mediated message to create a false belief in the receiver of the message". This is manifested through stealing users' identities, creating phoney webpages to hack into users' bank accounts and fronting false businesses through which unsuspecting members of the public are swindled. Deception has been identified as a regular occurrence in many daily activities (Hancock et al. 2007). Although studies have identified deception as usually being spontaneous, Whitty et al. (2012) observed that lies are also planned, especially in asynchronous interactions - as is the case on the webpages which are being studied. Hancock further classifies digital deception into: identity-based deception (realised through "false manipulation of a person's or organization's identity", see Palasinski and Bignell 2015, 6446) and message-based deception (which involves deception in the communication between two or more interlocutors).

One must, however, note that there are overlaps in this dichotomy. Through a computerised text analysis of online dating data, Toma and Hancock (2010) identify two forms of linguistic cues in digital deception - emotional (negative emotion words, negation and psychological distancing) and cognitive (split into exclusive and motion words). The underlying assumption in these studies is that language is central to deceptive practices online (Choudhury 2014). This is supported by Buller et al. (1996, 269), who identify language as a "key component of deceptive behaviour", what Galasinski (2000, viii) regards as the "primary mechanism by and through which a deceptive message can be passed from the deceiver to the target".

Choudhury (2014) identifies the use of sense words as hackneyed in deceptive language, but also observes other-oriented pronouns and references, speech disfluencies, as well as linguistic hedges for the purpose of "content mitigation" (Fraser 2010, 201, as quoted in Choudhury 2014). However, it must be stressed that Choudhury (2014) used both textual and oral data whereas the present study is wholly reliant on the former. Hancock et al. (2007) explore the linguistic patterns and peculiarities of deceptive communication online and find that there are identifiable markers of deceptive language even in computer-mediated communication. For instance, third-person pronouns (singular and plural) were identified as more preponderant than first-person singular pronouns in order to shift the focus from the deceiver to others.

Armistead (2011) and Arciuli, Mallard and Villar (2010) also observe that linguistic analyses and identified linguistic cues could potentially yield refreshing insights into the detection of digital deceptive practices. This is corroborated by Schafer $(2007,40)$, who indicates that deception in digital texts is realised through a "constellation of cues".

In addition, the linguistic analysis of digital deception has been studied with respect to varying platforms, extending across domains such as online dating, scam mails, phishing (obtaining sensitive information for fraudulent purposes), (micro)blogs, etc, including in Blommaert and Omoniyi (2006), Heyd (2008), Chiluwa (2010, 2015a), Okafor and Unachukwu 
(2015), and Taiwo (2012, 2017). Taiwo (2012) focuses on a metafunctional analysis of email scams and identifies a linguistic metamorphosis from an assertive and confident language use in early scam correspondence to a "non-confident, naïve, vulnerable, and ignorant" one in more recent scam texts, all geared towards achieving their persuasive tenor. However, studies on the linguistics of digital deception in Ponzi schemes are rare, with very few examples (cf. Luukkonen 2014). This earlier work studied an American Ponzi scheme from the perspective of persuasion with a focus on three integral viewpoints - the medium, the audience and the deceiver. The present study seeks to provide further insight into a banal yet understudied phenomenon. Ponzi schemes constitute platforms for digital deception because they are essentially created to swindle unsuspecting and greedy investors. The focus of this work is the discursive features and markers of deception in Nigerian online Ponzi schemes.

\section{Dimensions of Internet Scams and the Proliferation of Ponzi Schemes in Nigeria}

Scams and fraudulent practices have grown in recent years, owing to advances in technology, and they come at a huge cost to economies (Zahra, Priem, and Rasheed 2007; Tian and Keep 2002). Fraudulent schemes are rife globally and have morphed over the years from Charles Ponzi's postal stamp scam to forms ranging from phishing, phone call frauds, email scams, identity theft, dating and romance scams, and so on. Gong, McAfee and Williams $(2014,1)$ elaborate on the proliferation of these schemes and their financial exploitation concerns as follows:

Modern frauds include Ponzi and pyramid schemes, securities frauds, corporate accounting financial scandals, medical and automobile insurance frauds, sophisticated art forgeries, the shell game, and the "Nigerian scam", to name just a few.

Internet-based scams have adapted to the terrain provided by technological advances in telecommunications and financial services. These online mass marketing frauds exploit mass communication media. The Federal Bureau of Investigation $(2001,1)$ defines internet fraud as:

any fraudulent scheme in which one or more components of the Internet, such as Web sites, chat rooms and e-mail, play a significant role in offering non-existent goods or services to consumers, communicating false or fraudulent representations about the schemes to consumers, or transmitting victims' funds, access devices, or other items of value to the control of the scheme's perpetrators ${ }^{1}$

While some of these frauds are reliant on mass marketing, casting a wide net and hoping that inquisitive receivers would fall in the trap, others use bulletin boards or social media platforms, "offer 'unbelievable' opportunities or 'get rich quick' schemes to subscribers/ browsers of such boards" (Fried 2003).

Moore, Han and Clayton $(2012,41)$ acknowledge internet scams as "postmodern" because while most of the subscribers are knowledgeable enough to comprehend prospective fraud,

See https://archives.fbi.gov/archives/news/testimony/internet-fraud-crime-problems. 
they go ahead hoping to make a "profit by joining early" and withdrawing their funds before the inevitable collapse. In a study of the forms, discourse structures and pragmatic analyses of email hoaxes, Heyd (2008) terms the proliferating internet-based scams as digital lies. However, while such scams are informal and faceless, web-based schemes exude an air of officialness and provide a verisimilitude of authenticity which encourages patronage from subscribers. Capitalising on widespread greed, contemporary scam artists either wilfully infringe the privacy of would-be victims or lure them through multifarious gimmicks. In addition to playing on their ignorance, these scams employ persuasive language and promises of financial gains to convince their victims. Such manipulative tendencies, whether employed online or in face-to-face relations, ensure that victims often live in delusion, unconvinced that they are involved in an intricately woven scam until the scammer has succeeded.

In Nigeria, swindling, deception and racketeering are subsumed under the nomenclature ' 419 '. A Nigerian creation, the 419 phenomenon has attracted and enjoys global attention (Igwe 2007, 6). Tive $(2006,3)$ ties the history of 419 to Section 419 of the Nigerian criminal code, a section dealing with fraud, "related to stealing, cheating, falsification, impersonation, counterfeiting, forgery and fraudulent representation of facts". The upsurge in the availability, affordability and subscription to the internet in Nigeria has had phenomenal implications on the social fabric of life (Taiwo 2010), and has inevitably led to the "increasing application of internet resources to the practise of digital deceptions/online financial scams" (Chiluwa 2010, 3), even finding intertextual references in Nigerian popular music (Onanuga 2020). In recognition of the global acknowledgement that Nigeria is arguably the headquarters of email scams (Smith 2007), Blommaert and Omoniyi (2006) identify the communicative content of such correspondence. They identify competencies along the line of technology, culture and linguistics, all of which are intricately woven by scammers in convincingly crafting their fraudulent proposals and in appealing to the sensibilities of prospective victims regardless of their locations.

Systematic fraudulent ventures have a history in Nigeria. These were initially started through pyramid schemes, which involved multi-level marketing that required old members' referral of newly registered participants to move up the ladder (Lewis 2012). The more people they introduced, the higher the dividends. Examples include the NOSPETCO Oil and Gas Company (which promised over 100\% return on investment), the 1991 Umanah E. Umanah established Resource Managers Nigeria Limited (which offered a 60\% return), Planwell Watershed, Arise and Shine Trust Company, and Forum Business Finance, among others. These schemes involved illegal entrepreneurs who were not recognised by regulatory bodies and who capitalised on public greed. This chequered cycle was a craze in Nigeria before the popularity of MMM, a Ponzi scheme, in 2016. MMM's popularity and substantial patronage encouraged the creation of more of such schemes. A Ponzi scheme, according to Black's Law Dictionary (Garner and Black 2009, 1278), is:

a fraudulent investment in which money contributed by later investors generates artificially high dividends for the original investors, whose example attracts even larger investments. Money from the new investors is used directly to repay or pay interests to old investors, without any operation or revenue producing activity other than the continual raising of new funds. 
While some of the scams under discussion exhibit traits of pyramid schemes, since they encourage and reward referral, this is not the norm. Unlike pyramid schemes which require down-lines sourced by the participants, Ponzi schemes operate via a peer-to-peer matrix and progress is not directly tied to personal promotion towards gaining new members. What is, however, not in doubt is that the more new members join, the faster the rewards come in. This undoubtedly encourages subscribers to join.

The hardship witnessed in Nigeria following the sudden fall of crude oil prices in the international market coupled with the stifling economic programmes of the newly elected government in 2015 kindled the urge for illicit money-making ventures to cushion the effects of the harsh economic situation. MMM made the first incursion in 2015, and gradually gained a reputation for providing substantial profits. Structured as a counter-hegemonic platform to rupture the deep-rooted global financial cycle instituted by the rich against the poor, the exchange of money was couched in the idea of providing help for someone and receiving one's initial investment plus enticing percentages as interest back. Obviously cyclical in administration, the attraction was in the fact that the higher the investment capital, the higher the profit. As the lengthiest period to recoup one's investment was a month, several individuals, buoyed by the promise of sudden success and blinded by greed, borrowed money to participate in the scheme. Some bank staff also, in advisory roles, persuaded their customers to invest in the Ponzi scheme in view of its high interest rate compared to the abysmal one provided by the banks. The tales of students who diverted their school fees and employees who deceitfully misappropriated official funds in order to make rapid earnings also came to light and made the news upon the collapse of MMM, roughly a year after its commencement. ${ }^{2,3}$

The scheme's sudden suspension of the 'Get Help' provision a week before the Christmas period in 2016 signalled looming troubles. The decision came on the heels of rumours that the so-called guiders, persons who were at the peak of the scheme's administration, had been making millions of naira without actually providing any help. This implied that they had been gaining massive amounts of money without putting anything into the scheme. Alongside this was the fear that the scheme might not be able to provide enough money to meet the huge number of people who had invested in it and awaited bumper payments towards the traditionally expensive festive period. Naturally, the suspension led to a panic, with participants unwilling to provide help, while those whose funds had matured were unable to retrieve their money. Although the scheme promised to stage a comeback in January 2017, a promise it indeed fulfilled, public trust had waned, and this was coupled with changes that the scheme introduced, which meant that investors from before 2017 were unable to get their funds. ${ }^{4,5}$ The dissolution into irrelevance of the MMM scheme was also fast-tracked by the emergence of tens of similar schemes which promised the same or even better percentage of returns on an investment. At the peak of the craze there were as many as 150 Nigerian

\footnotetext{
See http://www.informationng.com/2017/03/student-laments-investing-school-fees-mmm-ponzi-scheme.html. See http://punchng.com/put-school-fees-project-money-mmm-varsity-students-lament/.

See https://www.bbc.com/news/world-africa-38340457.

See https:/www.pulse.ng/bi/finance/ponzi-scheme-mmm-returns-and-clearly-states-that-there-is-no-money-backguarantee/ekxkvl0.
} 
Ponzi schemes with an online presence (Onanuga and Taiwo 2019). In addition to the use of websites to promote their activities, these schemes have further used chat platforms like WhatsApp to accelerate the spread and reach of their activities. The patronage of these schemes cut across all social and educational divides. While the underlying motivation was the desire for rapid financial gains, the present study attempts an analysis of the language use on the schemes' webpages with the assumption that these pages, as advertisements, contain tools for convincing and attracting existing and prospective participants.

\section{Stance and Linguistic Engagement in Digital Discourse}

As in all human interactions, language is an integral feature on digital platforms. In the context of deceptive communication, Buller's and Burgoon's Interpersonal Deception Theory (1996) foregrounds the fact that "interaction between a sender and a receiver is a game of iterative scanning and adjustments to ensure deception success" (Tsikerdekis and Zeadally 2014, 75). Scammers employ various linguistic features to convince and appeal to the sense of reasoning of readers, thus widening the net for prospective victims. Stance constitutes one of those linguistic strategies (Taiwo 2016), with Chiluwa and Odebunmi $(2016,98)$ describing Biber's notion of stance as the theoretical concept "used to describe how speakers or writers express their viewpoints, opinions, judgements and attitudes about a topic being conveyed through lexico-grammatical options". Ochs $(1990,2)$ identifies two forms of stance as epistemic and affective, where epistemic stance is a "socially recognised disposition" while affective stance is a "socially recognised feeling, attitude, mood or degree of emotional intensity". Because they are social-oriented, these two forms of stance enable a writer to "stamp their personal authority onto their arguments or step back and disguise their involvement" (Hyland 2005, 176). Since communication involves both referential and non-referential information, words/ expressions are complemented by the attitudes, emotions, feelings, moods or dispositions of the speakers or writers. Through stance, one can therefore identify and deconstruct writers and their texts since they provide clues about themselves, their judgements, opinions and commitments, as well as their relationship with others (Chiluwa 2015b, 1).

Relying on the interpersonal aspect of discourse, which is established from Halliday's Systemic Functional Linguistics, stance is used to depict the construction of social roles, identities and relationships via language use. A close concept to stance with regard to the interpersonal aspect of discourse is engagement. This emanates from Martin and White's (2005) theory of evaluative language, which appraises the negotiation of meanings among interlocutors (Križan 2016). Martin and White $(2005,94)$ further assert that the appraisal split into three main aspects: Attitude, Engagement and Graduation - involves the analysis of "meanings in context and towards rhetorical effects rather than towards grammatical forms". Engagement evaluates a speaker's commitment and occurs when "writers acknowledge and connect to others, recognising the presence of their readers, pulling them along with their argument, focusing their attention, acknowledging their uncertainties, including them as discourse participants and guiding them to interpretations" (Hyland 2005, 176). These linguistic perspectives are acknowledged in the current study, as emphasis is placed on stance and linguistic engagement, commissives, politeness strategies and narrativity, and how these are used to negotiate and establish social presence and obliterate distance for the purpose 
of persuasion and deception. I contend that these discursive features are central to digital deception since "all forms of frauds on the internet begin from the point of using language in a particular way, to entertain, persuade and eventually convince" (Chiluwa 2010,3).

\section{Methodological Details}

Drew and Drew (2010) underline the necessity of quantitative and qualitative assessment of Ponzi schemes in order to forestall their recurrence. The present study is qualitative, and the data is a self-compiled corpus from the webpages of 50 Nigerian online Ponzi schemes. The primary selection criterion was the popularity of these webpages based on user traffic. This is apposite, because the webpages serve as platforms for advertisement and investor participation, and both prospective and existing investors visit them. Aside from the textual information from the site creators, we integrate instances of investor feedback, as documented on the pages, in the discussion. The analysis relies on the postulations of Critical Discourse Analysis (henceforth CDA). CDA perceives language as social practice, and therefore studies the contexts of language as crucial in ascertaining the meanings and implications behind texts and utterances. This theoretical perspective is applied to Galasinkis (2000) three-fold strategy - deception, persuasion, and manipulation - which is appropriated by online scammers. We accommodate these tripodal strategies in the identification and analysis of language use in Nigerian Ponzi data. Chiluwa and Chiluwa (2020), in their engagement of indexicality in Nigerian Ponzi schemes, posit that CDA allows the interrogation of how language is used to legitimise deceit while exploiting members of the public. The power of language in deceptive practices also ensures that people often still cling to deception even when it becomes obvious that there is the possibility that they are being lied to (Vrij, Mann, and Leal 2012). Language use has also been found to correlate to appealing to certain affinity groups (Bosley and Knorr 2018).

The overarching theoretical frame of CDA used in this study comes from Fairclough (2003), and this perspective considers discourse analysis as interfacing between a focus on texts and the 'order of discourse', which refers to the social structuring and networking of social practices. To Fairclough, texts embody elements of social events which have implications in the real world. Consequently, and while targeted at analysing discursive practices within texts, the theory is employed to focus on how Ponzi discourses construct stance and linguistic engagement, commissives, politeness strategies, and narrativity through language choices and how these contribute to positive self-presentation and ideology in the process of persuasion and ultimately, manipulation and deception. In achieving this, we analyse the nexus of linguistic structures and relate textual structures to ethnographic/contextual realisations.

In our subsequent analysis, we consider naming, use of formulaic expressions and politeness strategies, suasive language, commissive acts, narrativity and their ideological implications in the achievement of digital deception within the domain of Nigerian Ponzi schemes. Formulaic expressions are verbal expressions that are fixed in form and imbued with attitudinal nuances (Ambele, Yusop, and Buddharat 2018). As used in this study, they play significant roles in shaping persuasion and politeness. Within this context also, politeness involves maintaining and saving face as well as claiming positive social values in the Ponzi narratives (Spencer-Oatey 2008; Sorlin 2017), while suasive language and commissive acts require the Ponzi scheme creators to use 
language to convince readers to take action and be committed to future actions, respectively. To further assert their identities as real and their products as authentic, these schemes use relatable stories to convince prospective participants. This is narrativity. Finally, these identified discursive features are related to the ideological significance of the Ponzi schemes in Nigeria.

\section{Analysis and Discussion of Findings}

\subsection{Naming in Ponzi Schemes: An Analysis of Structures}

Names play important roles in businesses. Consequently, to attract attention while also conveying the focus of the business, owners use names that are also forms of advertisements. Since the concerns of Ponzi businesses lie in convincing the public on the genuineness of their ability to provide instant financial gains with minimal effort or investment by participants, their names are targeted at legitimising their illegitimate trade. In addition and as exemplified below, such schemes possess names that are substantially nominal groups. In English grammar, nominal groups are noun-headed, and can be simple or complex. The possible structures realisable in the nominal group are: Head: (Modifier)+Head, Head+(Qualifier); (Modifier) + Head $+($ Qualifier $)$. The bracketed structures are not obligatory. Below is an analysis of the names of the schemes:

\section{Nominal Groups:}

H: Help Givers, Greenspeer, Loopers, GiversLink, MMM, NNN, Ogive, Crowdrising, Somapay, Doublecash.me, Twinkas, Liftcareer, Farewealth, Exearn, MegaCycler, eCooperative, Salicyls, Kaynation, Claritta, Bravelink Nigeria, MoneyLink, QMM, iCharity, Payee Cycler, Tetris Mart

MH: iCharity Club, Givers' Forum, Money Hub, Determined Millionaire, Soft Cash, Spring Cash, Joyful Donor, Ultimate Cyclers, Mingler's Donations, Accumulating BTC, Mutual Grant, Team 1 Bitcoin, Pay Doublers, Naira Cyclers

MMH: MyLibertyFamily, Money Link Forum, My Charity Loan, The Helper's Club, Quick Cash Forum, ExtraCoolCash, My Sure Cash, Instant Money Doublers, Wealth Creation Tip, My Charity Loan, Money Flow PH Room, Paradise Payment Nigeria

MHQ: Changing Lives Online; 360 Money Plus

It is notable that the MHQ structure, which is the most complex of the nominal group structure, is rarely realised. This suggests that Ponzi scheme creators target simple and catchy names for their schemes (Burgoon et al. 2003; Newman et al. 2003; Picornell 2011), as seen in the profuse realisations of $\mathrm{H}, \mathrm{MH}$ and $\mathrm{MMH}$. These structures are usually heavy with noun heads and pre-modifiers, suggesting that images and descriptions are involved in the names. There is also a functional conversion involving $e$ Co-operative, normally an adjective but which, when used as a name, has been converted to function as a noun. Also explicitly identifiable is the schemes' focus on money/wealth creation, as the names indicate - cash, money, pay(ment), naira and wealth. However, down-toners that detract from the fraudulent nature of the schemes are also rife in the names. Down-toners are words or phrases which reduce the force of another word or phrase (Strohm and Klinger 2018) and some of these 
are donations, charity, grant, donor, givers, and helper, which serve as validation for the illegal practices. These names also indicate that since the schemes are created online - signals which are showcased in the retention of domain names in some of the names - the customers they seek can come from both within and beyond Nigeria. While the names in Ponzi schemes have a preponderance of nominal phrases, some non-phrasal naming realisations are as follows:

Simple sentence - Money Is Power

Command without Vocative - Get Help Worldwide, Help Naija, PairMe, Give2me, PairMe, Smile 2 Charity

Another identifiable feature in the names involves the use of internet language, which is a testament to the contemporariness of the schemes. This also constitutes a delineation of social space, since such the writing styles are global conventions of internet language (AlKadi and Ahmed 2018). Crystal (2011) notes the growing informality of language online, recognisable in the use of numbers to replace words, deletion of space between letters and words, abbreviations, use of (i) and (e) as premodifiers to adjectives as well as the addition of domain names to word endings. Apart from signalling digital flexibility and prowess, the features have emotive influences: they reveal the creators as socially close to the users since they share less formal and official linguistic forms. This is useful since the ideological framing of the platforms is financial leverage for marginalised demographics. Instances in the data are:

iCharity, eCo-operative, Doublecash.me, Give2me, Smile 2 Charity, ExtraCoolCash, MoneyLink

Beyond the naming strategy in Ponzi schemes, the names also have riders, which function as sources of additional information to a main item. In the Ponzi scheme advertisements, riders are manipulatively wielded to provide legitimising information to the readers. These extend from stimulating a sense of community and togetherness, encouraging unrestricted giving and 'helping', and preaching financial prosperity. Some of such realisations are:

Let's join hands (360 Money Plus)

Your true source to inexhaustible income (Better Naija)

Your journey to financial freedom starts here (Revo Squad)

Our vision is to provide a financially stable future for our clients (Cash Rush)

Let's free you financially (Executive Donations)

A community of people providing each other financial help on the principle of gratuitousness, reciprocity and benevolence (Get Help Worldwide)

Getting help to own your house (Givers Forum)

Community of Helpers (HelpGivers)

Together, we can change the world (MMM)

Givers never lack! (GiversLink)

Community of people helping people (NNN Nigeria)

Built by the people for the people (Ultimate Cycler) 
We Rise By Lifting Others (The Helpers' Club)

Giving opens the way for receiving (Twinkas)

The lexical range revolves around the idea of membership which will result in financial freedom. The riders affirm the stance established in the names - businesses which are solely for financial benefits - however, the discursive thread is extended through the riders which seek to push the onus onto the members. Consequently, the realisations indicate that the schemes are altruistic in orientation. Through the community which has been established, financial security, monetary freedom, and communal joie de vivre, among other positive values, are encouraged. The underlying ideological implication is that being financially stable will ultimately lead to equitable global political structures, since the current structures are hinged on discriminatory dichotomies - Developed vs. Developing, Rich vs. Poor, Elite vs. Masses, etc. The simplicity and directness of expression evoke Holt and Graves' (2007) assertion that scammers intentionally employ simple structures and expressions in their correspondence. This may be in order to minimise the risk of making avoidable mistakes or providing too much information which may breed doubts in prospective subscribers. This consciousness is however underlain by the desire for control (Leeper Piquero, Exum, and Simpson 2005).

\subsection{The Use of Formulaic Expressions and Politeness Strategies}

The schemes employ the use of openings which constitute introductory lines to welcome participants to the schemes. These are realised through the use of formulaic expressions and serve as politeness strategies to assure participants. Some examples are:

\section{Welcome to Claritta (Claritta)}

Welcome to Executive Donations (Executive Donations)

Hello people (NNN)

These expressions lend legitimacy and officialise the claims made by the schemers, since they imitate linguistic practices in other legitimate businesses. In addition, rhetorical questions to whet the appetite are also identified, as in the following examples:

\section{Are you financially stranded? (Changing Lives Online) \\ So you have decided to participate in BetterNaija.org, what to do? (BetterNaija)}

The use of rhetorical questions serves as an emotional bridge between the scheme creators and the viewing public. It familiarises the prospective subscriber with the purpose of the schemes as well as specifies the need which the subscriber yearns to have met. According to Jacobs and Schain (2011), such emotional framing through language use often interferes with a prospective participants' logical reasoning, especially as there is a strong desire to make money.

Politeness strategies are also marked in the information pages of the Ponzi schemes. According to Taiwo $(2012,150)$, politeness strategies are usually found in the introductory lines of deceptive correspondences. They are used to establish a "decent personality" and positive face/ affect in the mind of the reader (Zhou et al. 2004), and help to maintain the "interpersonal identity of individuals in communication" (Scollon and Wong Scollon 1995, 34-36). 
Politeness is used to reinforce the ultimate desire of the scheme creator in engendering an interpersonal affiliation which will ensure that the reader is convinced to commit to the scheme (Holt and Graves 2007). Examples of this are:

You can join me together let's make this platform a source of income for us all... (PairMe)

The auxiliary verb 'can' for instance is used to suggest that the prospective subscriber is not being forced to participate in the scheme, and that the eventual decision to do so lies with them. However, the progression remarked by the use of pronouns - from 'you' to 'me' and to 'us' - suggests the aim of the schemers.

It sounds like magic, this is how it works. I am telling you today that with this you can achieve your financial dreams. The registration is totally free of charge so you don't have to pay to register. Making money in Nigeria is no longer hard, all you need to do, is just to be smart about the money making thing. (Arigak)

Lexical choices which reinforce the scheme creators' need to establish and sustain interpersonal affiliations in the above excerpt are the juxtaposition of pronouns (you/your vs. I/Me) and the assertion of shared interests (together, network, us, financial dreams, making money). In the use of pronouns, we identify that there is an overt reference to progression - you + me = us. Language is therefore used as a signal to inform prospective subscribers that once they become members of the scheme, "making money... is no longer hard". This establishes a form of alternation between in-groupness and out-groupness, where only those who are willing to belong are provided with the secrets of success, thus breaking the chain of poverty. The realisations constitute indexical positioning, which Chilton (2004) regards as indicative of the use of language in the construction of socio-cultural identities and ideological leanings. Newman et al. (2003) affirm that deceptive communicators tend to avoid or make minimal use of self-oriented references, since such linguistic choices suggest agency or taking ownership of a statement. On the other hand, the significant presence of other-focus references assists in maintaining a distance from the lies being told. However, some webpages simply go ahead with an introduction of the scheme:

\section{iCharity is an international network of donors. (iCharity)}

Pairme is a special group (community) of believers coming together to selflessly help each other in times of need with no conditions attached in the principle of sowing and reaping, gratuitousness, reciprocity and benevolence. (Pairme)

The anonymisation identified with the choices of pronoun use, the presence of emotionally toned words as well as politeness-laden expressions assist in the establishment and assertion of a linguistic style for deceptive communicative practices (Feldman Barrett, Williams, and Fong 2002).

\subsection{Use of Suasive Language}

In engendering inclusivity, the schemes employ language to convince prospective subscribers of their philosophy. For instance, MMM states that it is a "community of people providing 
each other financial help on the principles of gratuitousness, reciprocity and benevolence". The promoters also state that the scheme is a "technical platform which helps millions of participants worldwide to connect those who need help with those who are ready to provide help for free" (see also Urowayino 2017). This resonates with the alluring proposition on which MMM is founded - that of rearranging the globally disproportionate distribution of wealth in society. The persuasive inclination is further emphasised with the constant reminder that the schemes are wholly 'donations' or 'help' from 'member to member'. This allays the fear of prospective participants who may thus readily conclude that the schemes are indeed established to tackle the status-quo and close the wealth gap. CrowdRising, while appealing to the sense of judgment of the reader, unequivocally affirms its genuineness as it says: "ZERO Admin Fees - and is totally free. No SCAMS, No gimmicks".

Some other forms of suasion are in the use of percentages, amounts and timeframes. These function as interest-sustaining strategies employed by digital scammers (Chiluwa 2009). According to Druyd (2005), scammers appeal to the greed of their prospective victims, and examples of this in the data are as follows:

Get $\mathbf{3 0 0 \%}$ of your donation in $\mathbf{2 4}$ hours

30\% in 30 days local currency; 50\% in $\mathbf{3 0}$ days BITCOIN (Get Help Worldwide)

Get 100\% (x2) of your investments minimum of 5 mins and maximum of 14 days (Loopers)

Provide Help, Get Help, Receive 30\% of the help you provided per month (MMM)

$\mathbf{4 0 \%}$ of investment in 5 hours (Salicyls.com)

Grow your money 35\% every 3 weeks (NNN Nigeria)

Apart from the use of textual financial inducements, some of the schemes also provide information on the number of times they have paid out to participants. This is to create an air of genuineness, formality, and professionalism. These realisations serve as reassurance strategies to encourage patronage (Cialdini 2001) and, in line with Choudhury $(2014,79)$, validate the assertion that "language is a key component of deceptive behaviour".

\subsection{Use of Commissive Acts}

Commisives are speech acts which "commit the speaker [...] to some future course of action" (Searle 1976, 11). In the data studied, commissives are employed by the scheme creators to inform the public and subscribers that their program is fraud-free and has rewarding prospects. Often incorporating directives in the promissory intent, this linguistic strategy is also used in building confidence in the smooth running of the schemes. Instances of such realisations are:

We don't update, We upgrade (Naira Propeller)

MMM PAYS! (MMM)

Join our community and start earning (BetterNaija)

NetElites is an online donation network, platform to connect ordinary people selflessly Join Now For More Cash (Xencash) 
Commissives are employed in the data simply for communicative and (re)assurance purposes to convince prospective victims to participate, since the endgame is actually to lure them for the scams. This realisation markedly contrasts with Adegbijas (1995) claim that the felicity or efficacy of commissives is hinged on the ability of a person who utters the act to have the wherewithal of fulfilling them. The flouting of this fulfilment requirement therefore implies that assertions are made only for the purpose of establishing belief and trust in prospective participants (Button et al. 2014), although the trust is subsequently broken by the scheme creator. Through the promissory statements and the resultant elicitation of commitments, claims like "NNN is owned by the participants" are engendered and reinforced. The use of language here for deceptive purposes is what Greenspan (2009) typifies as appealing to gullibility or a foolish act, since the assurance being suggested should otherwise serve as red flags to discerning public. He defines gullibility as an event/situation when "someone goes ahead with a socially or physically risky behavior in spite of danger signs, or unresolved questions which should have been a source of concern for the actor" (Greenspan 2009).

\subsection{Narrativity and the Construction of Deception}

Many previous studies on lying and deception note that liars often refrain from being expressive and wordy in their correspondence. This is because wordy messages may lead to the provision of more than the necessary details and thus raise the chance of errors which may give them away (Burgoon et al. 2003; DePaulo et al. 2003). However in this study, as well in some more recent studies like Zhou et al. (2004) and Hancock et al. (2007), it was found that the earlier assertions may not be altogether correct. Instead, these deceptive correspondences/ texts were found to contain more words. One significant strategy for this is through the use of narrativity. In line with Heyd (2008), narrativity is an elementary and important quality of human discourse. It provides a stream of discursive interactivity reliant on the shared experiential knowledge of realities and aiding smooth exchanges between the interactants.

Applied to the data in this study, narrativity involves the creation of make-believe stories and exaggerated assertions in a bid to be convincing. Consequently, promises are made and a sense of camaraderie is cultivated. While promising bogus returns, the discourse reiterates the sense that the schemes are established to reverse the injustices long sustained in global financial practices which further empower the rich and trample upon the poor (Krige 2012). PairMe, one of the data sources, puts it thus: "the goal here is to willingly help one another overcome the world unjust financial system that helps the rich to get richer while the poor get poorer". The narrative is further asserted in such a way that while the participant obviously knows that the schemes do not have a workable and long-lasting business model, against their better judgment they invest with the belief in the conspiracy theory that they are merely retrieving or enjoying from the funds which the rich had kept for themselves. Some participants also knowingly risk their investment, hoping that the schemes do not collapse before they reap the benefits. The narratives constructed online however are two-fold - from the scheme creators and from the participants (albeit at the instigation of the creators). The data from the scheme creators is emphatic in its insistence on the veracity of their promises, while the testimonies from subscribers serve as validation of the genuineness of the schemes. Samples from the Ponzi narratives are: 
NNN is owned by the participants. It's a community by the people and for the people. A team of freedom lovers in America headed by an influential Yoruba man came up with a logic ad tested it offline in New York City in 2014. In September 2015, these men held a conference in VI Lagos where they introduced logic... Today, the founders choose to remain anonymous as they have no control over the system, it is automated with a secret code that no one knows. NNN website is run and hosted by the participants - the live chat, support, seminars, etc. So you too can help as NNN belongs to me and you, bring your talents and suggestions to work for NNN and let us make it better. (NNN - Scheme creator)

A worldwide channel to connect participants to share donations and receive incentives in return. A group of ordinary people, selflessly helping each other. (Monie Hub - Scheme creator)

NetElites is an online donation network, platform to connect ordinary people selflessly Which is involved in helping each other. Netelites Login have aimed to empower and improve upon the standard of living, The procedures and everything involved is very simple and straight forward: one participant to present his choice other candidates and above, the Giver receives help from two other participants according to the package chosen. The system is based on the latest technology and designed to designed concept ... I am telling you today that With this you can achieve your financial dreams. Making money in Nigeria is no longer hard all you need to do, is just to be smart about the money making thing. (Arigak - Scheme Creator)

My name is Joshua but people call me Commando and I live in Lagos. I am a member of MMM Nigeria. On the 31 st of October, I provided help 500,000 and on the 2nd of November I provided another help of 1,000,000 totalling 1,500,000. On the 29th of November, I got help of 1,945,000. (Participant)

The narrative presented by NNN relies on a number of Nigerian contextual realities. For one, the central creator is said to be Yoruba, a member of one of the three dominant ethnic groups in Nigeria, thus appealing to Nigerians since, unlike MMM for instance, which has Russian roots, it is 'owned' by a fellow citizen who thus probably has some altruistic sense at heart. By positioning the movement of the idea and establishment of the scheme from the United States of America (New York) to Nigeria (Lagos), the business acumen of these "freedom lovers" is established. Lagos and New York are business hubs, and these references depict the scheme creators as professionals in their business. More attractive for prospective participants however is the surrendering of 'control' so that "NNN belongs to me and you". This is strengthened with the request for "talents and suggestions" to move the platform forward. These forms of narratives are sustained in the information from Arigak and MonieHub. MonieHub claims that it has a global orientation, while its motivation is to aid "a group of ordinary people, selflessly helping each other". This view is repeated in the message from Arigak. These are ultimately aimed at convincing prospective participants on the authenticity of the promises as well as the reality of the payments of the schemes, as against those of some other schemes which have crashed. Expressions such as "Nobody Will Scam You", "All Donations are made directly to member bank account", "There is no central account where all the system money flows into" are employed to appeal to the emotions of subscribers. The creators also assert their neutrality in influencing the directions of the schemes, insisting that 
the sustenance, survival and efficiency of the schemes lie in their consistency and effective marketing. On the other hand, the participants' testimonials, often with the support of the scheme creators, serve as launching pads to encourage more patronage. Hinged on structural equivalence and repetition in the form of Personal pronoun (I) + Active lexical verb (live, am, provided, got), there is the insistence on the testimonies of 'ordinary' people, since these are deemed weighty in convincing the public to also exploring the stated opportunity. These are made more real with the use of names and other specifiers of identity. Consequently, what is evoked is the sense that if someone like me has been benefiting, why should I not do the same? What is further remarkable in some of these narratives is that they betray grammatical, vocabulary, and orthographic (punctuation, run-on sentence and paragraphing conventions) infelicities (Holt and Graves 2007; Schaffer 2012) that ordinarily should serve as a warning to prospective subscribers. These resonate with Woker's $(2003,237)$ claim that "some are highly sophisticated operations with skilled and articulate promoters whilst others are quite crude."

In addition, the narratives also rely on the introduction of new terminologies, particularly those related to virtual currencies like Bitcoin, Ripple, Monero, Litecoin, Dogecoin, Onecoin, etc., which are gradually gaining ground in their use for internet-based transactions. The schemes capitalise on the obvious ignorance of most participants through the provision of naira or dollar equivalents of the virtual currencies, which makes the proceeds eye-catching and mouth-watering. These realisations are in line with Chiluwa (2009), who recognises that narrativity is a potent resource wielded as a discourse strategy by online scammers in strengthening their proposals. Newman et al. $(2003,671)$ also submit that a successful lie usually involves "the manipulation of language and the careful construction of a story that will appear truthful".

\section{Ideological Implications}

It is important to stress that these rhetorical and linguistic findings do not exist in a vacuum. This is in line with Fairclough's (2003) claim that language use has implications in the real world. Consequently, the composers of the Nigerian Ponzi narratives have ideological bases for their language use. To Van Dijk (2006, 115), ideologies organise a group's "identity, actions, aims, norms and values, and resources as well as its relations to other social groups". In this study, ideology implies Ponzi scheme creators' self-representations through linguistic choices, as already identified above, and what these are used to achieve with (prospective) subscribers. An obvious aim is embodied in the interventionist representation of the self which the scheme creators assert. They recognise the glaring poverty endemic in Nigerian society and the need for people to find additional sources of income. They capitalise on this by presenting themselves as facilitators and opportunity-creators who are solely interested in the financial independence of the public. This altruistic self-portrayal is further achieved without employing a forceful, in-your-face marketing strategy (Rejón-Guardia and MartínezLópez 2014). Instead of pressuring prospective victims, they use of subtle linguistic markers (lexis, formulaic polite expressions, positive narratives, etc.), textual financial inducements (through the use of percentage profits), emotive expressions, and testimonies from existing subscribers (Onanuga 2017; Onanuga and Taiwo 2019). 
Allied to the preceding ideological construct is the overt manipulation which is used to convince subscribers that they will enjoy financial independence and leverage through participation (Woker 2003). Relying on claims that they seek to rupture perceived global financial strangulation of the lower class of the society (Krige 2012), the scheme creators reinforce the Western stereotypes of African economic situations (Smith 2009) and state their readiness to contribute to financial freedom. MMM boldly reveals this as its 'ideology' when it states: "the goal is not the money. The goal is to destroy the world's unjust financial system". Consequently, participants are motivated to join and provide mutual aid, even when the sources of the promised profits are unclear. Justification for ignoring pragmatic reasoning is aptly captured by the rider from Twinkas: "giving opens the way for receiving". This has religious undertones, evoking Holt and Graves' (2007) identification of religious motifs in scam narratives. The financial objective in Nigerian Ponzi schemes is further reinforced through the repetitive use of percentages, figures and sums alongside images of currencies and gold coins. One must be mindful of the contextual peculiarities here, as targets are residents of developing countries which are often subject to economic and social challenges. Consequently, the schemes seek to exploit the loopholes in such systems.

The emphasis on communality and the cultivation of a sense of assistance in the narratives is used to divert attention from the improbabilities of the claims and limitations of the schemes. Since financial freedom with minimal entrepreneurship or effort constitutes the claims of the schemes, one encounters ideological couching of activities through opaque expressions like "peer to peer direct donations" and "Provide Help, Get Help" to refer to the exchange of funds. This ensures that the participants do not see the schemes for what they really are. In addition, participants are urged to encourage more members to join. The introduction of new members implies that more people are being rescued from poverty. More importantly however, the future of the schemes relies on the continuous provision of help (Basu 2014). By making participants believe that they function within a community of 'helpers', the sense of risk is shared and the fear of collapse is suspended. Regrettably, after the collapse of MMM, it was identified that the bulk of the funds went to the guiders or scheme creators who siphoned the accrued monies while circulating leftovers among subscribers. The appeal to the economic situation and emotions of the public are in tandem with Greenspan's (2009) claim that these factors contribute to the success of most Ponzi schemes. In realising this, we have justified the role of language as a legitimising tool.

\section{Conclusion and Recommendations}

What's remarkable about Ponzi's legacy is that, no matter how many times investors lose money, new schemes keep coming forward. And greedy, naïve people of all sorts line up to throw good money after bad. (Walsh 1999, 14)

An analysis of the discursive practices in Nigerian Ponzi schemes reveals linguistic cues to deception and persuasion in the public engagement and information dissemination strategies of the scheme creators, and similar conclusions have been reached by Armistead (2011), Arciuli, Mallard and Villar (2010) and Schafer (2007). The present study identifies that language use in digital scams appropriates several discursive strategies. For one, there is a reliance on the 
establishment of cordiality through the use of polite expressions, endearing introductions, juxtaposition of pronouns as well as through the use of simple and direct expressions. In addition, lexical range (with words expressing money and the ease with which it can be made), reassurance strategies and the establishment of the sense of community through stance and narrativity are intentionally harnessed as discursive strategies by Ponzi scheme creators. This particular use of language in scam/deceptive discourses helps in attracting participants and deceiving them into committing their funds. They are then subsequently ripped off. Despite the fact that the texts on the homepages of the Ponzi schemes contain grammatical and stylistic errors, they enjoyed patronage across the socio-economic and educational divides of the Nigerian populace (Blommaert and Omoniyi 2006; Chiluwa 2010). Tive (2006), Tanfa (2006) and Adomi and Igun (2008) recognise the transnationality of scams in terms of their language use, hinged on the necessity to appeal to a generic audience. Thus language is used to deceptively validate the needs and desires of a wide range of prospective victims. The gimmick succeeded in Nigeria since the overriding need for financial security in the face of a biting economic crisis during the period led many citizens to throw caution to the wind. In addition, widespread unemployment and underemployment meant that people readily explored alternative means to ensure their survival.

Linguistic studies on digital deception and online fraudulent practices draw attention to realisations and events which constitute safety concerns for those online. Not only are they exposed to identity hacks and online data mining through the kinds of platforms they engage with, they are also susceptible to manipulations by scammers and their schemes. More linguistic studies are thus recommended on the discursive practices used in Ponzi schemes, because scam discourses have been recognised to be constantly mutating (Walsh 1999), especially when hitherto established deceptive styles no longer yield victims. It is further recommended that researchers should carry out multimodal analyses of Ponzi scheme narratives, as this will provide insights into how texts and images are employed in what is an international cybercrime.

\section{References}

Adegbija, Efurosibina. 1995. “I, Major-General X'. Discourse Tacts in Military Coup Speeches in Nigeria." Text 15 (2): 253-70. https://doi.org/10.1515/text.1.1995.15.2.253.

Adomi, Esharenana, and Stella E. Igun. 2008. "Combating Cybercrime in Nigeria." The Electronic Library 26 (5): 716-25. https://doi.org/10.1108/02640470810910738.

Al-Kadi, Abdu M. Talib, and Rashad Ali Ahmed. 2018. "Evolution of English in the Internet age." Indonesian Journal of Applied Linguistics 7 (3): 727-36. https://doi.org/10.17509/ijal.v7i3.9823.

Ambele, Eric A., Yusop Boonsuk, and Chamaiporn Buddharat. 2018. "Processing English Formulaic Expressions in Situation-Bound Utterances: Strategies Used by Francophone ESL Learners in Thailand." Arab World English Journal 9 (3): 163-75. https://doi.org/10.24093/awej/vol9no3.11.

Arciuli, Joanne, David Mallard, and Gina Villar. 2010. “Um, I can tell you’re lying': Linguistic Markers of Deception versus Truth-Telling in Speech.” Applied Psycholinguistics 31 (3): 397-411. https://doi. org/10.1017/S0142716410000044.

Armistead, Timothy W. 2011. "Detecting Deception in Written Statements: The British Home Office Study of Scientific Content Analysis (SCAN)." Policing: An International Journal of Police Strategies \& Management 34 (4): 588-605.

Basu, Kaushik. 2014. "Ponzis: The Science and Mystique of a Class of Financial Frauds." World Bank Policy Research Working Paper (6967). https://papers.ssrn.com/sol3/papers.cfm?abstract_id=2466780. 
Blommaert, Jan, and Tope Omoniyi. 2006. "Email fraud: Language, Technology, and the Indexicals of Globalization.” Social Semiotics 16 (4): 573-605. https://doi.org/10.1080/10350330601019942.

Bosley, Stacie, and Knorr Maggie. 2018. "Pyramids, Ponzis and Fraud Prevention: Lessons from a Case Study." Journal of Financial Crime 25 (1): 81-94. https://doi.org/10.1108/JFC-10-2016-0062.

Buller, David, and Judee K. Burgoon. 1996. "Interpersonal Deception Theory." Communication Theory 6 (3): 203-42. https://doi.org/10.1111/j.1468-2885.1996.tb00127.x.

Buller, David, Judee K. Burgoon, Aileen Buslig, and James Roiger. 1996. "Testing Interpersonal Deception Theory: The Language of Interpersonal Deception." Communication Theory 6 (3): 268-89.

Burgoon, Judee. K., J. P. Blair, Tiantian Qin, and Jay F. Nunamaker Jr. 2003. "Detecting Deception through Linguistic Analysis." In Intelligence and Security Informatics, First NSF/NIJ Symposium, ISI 2003, Tucson, AZ, USA, June 2-3, 2003 Proceedings, edited by Hsinchun Chen, Richard Miranda, Daniel D. Zeng, Chris Demchak, Jenny Schroeder, and Therani Madhusudan, 91-101. https://doi. org/10.1007/3-540-44853-5_7.

Button, Mark, Carol McNaughton Nicholls, Jane Kerr, and Rachael Owen. 2014. "Online Frauds: Learning from Victims Why They Fall for These Scams.” Australian \& New Zealand Journal of Criminology 47 (3): 391-408. https://doi.org/10.1177/0004865814521224.

Chilton, Paul. 2004. Analysing Political Discourse: Theory and Practice. London: Routledge.

Chiluwa, Innocent. 2009. “The Discourse of Digital Deceptions and '419' Emails.” Discourse Studies 11 (6): 635-60. https://doi.org/10.1177/1461445609347229.

—. 2010. "The Pragmatics of Hoax Email Business Proposals." Linguistik Online 43 (3): 3-17. https://bop. unibe.ch/linguistik-online/article/view/409/648.

—. 2015a. "E-mail Fraud." In International Encyclopedia of Language and Social Interaction, edited by Karen Tracy, Cornelia Ilie, and Todd Sandel, 503-8. Boston: Wiley Blackwell.

—. 2015b. "Radicalist Discourse: A Study of the Stances of Nigeria’s Boko Haram and Somalia's Al Shabaab on Twitter." Journal of Multicultural Discourses 10: 214-35. https://doi.org/10.1080/17447143.2015 .1041964 .

Chiluwa, Innocent, and Akin Odebunmi. 2016. "On Terrorist Attacks in Nigeria: Stance and Engagement in Conversations on Nairaland." Communication and the Public 1 (1): 91-109. https://doi. org/10.1177/2057047315624926.

Chiluwa, Isioma M., and Innocent Chiluwa. 2020. “'We Are a Mutual Fund:' How Ponzi Scheme Operators in Nigeria Apply Indexical Markers to Shield Deception and Fraud on Their Websites." Social Semiotics. https://doi.org/10.1080/10350330.2020.1766269.

Choudhury, Farzana. 2014. "Can Language Be Useful in Detecting Deception? The Linguistic Markers of Deception in the Jodi Arias Interview." Diffusion - The UCLan Journal of Undergraduate Research 7. https://diffusion.uclan.ac.uk/wp-content/uploads/2019/07/16-58-1-PB.pdf.

Cialdini, Robert. 2001. Influence: Science and practice, 4th ed. Boston: Allyn \& Bacon.

Crystal, David. 2011. Internet Linguistics: A Student Guide. London: Routledge.

DePaulo, Bella M., James Lindsay, Brian Malone, Laura Muhlenbruck, Kelly Charlton, and Harris Cooper. 2003. "Cues to Deception." Psychological Bulletin 129: 74-118.

Drew, Jacqueline M., and Michael E. Drew. 2010. “The Identification of Ponzi Schemes." Griffith Law Review 19 (1): 51-70. https://doi.org/10.1080/10854668.2010.10854668.

Druyd, M. 2005. "I Brought You a Good News': An Analysis of Nigerian 419 Letters." Proceedings of the 2005 Association of Business Communication Annual Convention, 1-11.

Fairclough, Norman. 2003. Analysing Discourse. Textual Analysis for Social Research. London and New York: Routledge.

Feldman Barrett Lisa, Nathan L. Williams, and Geoffrey T. Fong. 2002. "Defensive Verbal Behavior Assessment." Personality and Social Psychology Bulletin 28 (6): 776-88. https://doi. org/10.1177\%2F0146167202289007.

Fraser, Bruce. 2010. "Hedging in Political Discourse." In Perspectives in Politics and Discourse, edited by Urszula Okulska and Piotr Cap, 201-14. Amsterdam: John Benjamins Publishing. https://doi. org/10.1075/dapsac.36.16fra. 
Fried, Robert B. 2003. "Cyber Scam Artists: A New Kind of .con.” SANS Institute Information Security Reading Room. Accessed November 26, 2019. https://www.sans.org/reading-room/whitepapers/ threats/cyber-scam-artists-kind-con-482.

Galasinski, Dariusz. 2000. The Language of Deception: A Discourse Analytical Study. London: Sage Publications.

Garner, Bryan A., and Henry Campbell Black. 2009. Black's Law Dictionary. St. Paul, MN: West.

Gong, Jiong, Randolph Preston McAfee, and Michael A. Williams. 2014. "Fraud Cycles." Social Science Research Network, February 14, 2014. https://doi.org/10.2139/ssrn.1762583.

Greenspan, Stephen. 2009. "Fooled by Ponzi (and Madoff), How Bernard Madoff Made Off with My Money." Skeptic 14 (4). https://www.skeptic.com/eskeptic/08-12-23/\#feature.

Hancock, Jeffrey T. 2007. "Digital Deception: When, Where and How People Lie Online.” In Oxford Handbook of Internet Psychology, edited by Adam N. Joinson, Katelyn Y. A. McKenna, Tom Postmes, and Ulf-Dietrich Reips, 287-301. Oxford: Oxford University Press.

Hancock, Jeffrey T., Curry Lauren E., Goorha Saurabh, and Woodworth Michael. 2007. "On Lying and Being Lied To: A Linguistic Analysis of Deception in Computer-Mediated Communication." Discourse Processes 45 (1): 1-23. https://doi.org/10.1080/01638530701739181.

Hess, Sarah, and Soltes Eugene. 2018. "Russia’s Greatest Ponzi Mastermind is Dead, but his Legacy Lives on in the Crypto World." Quartz Online, April 25, 2018. https://qz.com/1259524/mmm-andbitcoin-russian-ponzi-mastermind-sergeimavrodi-is-dead-but-his-legacy-lives-on-in-crypto/.

Heyd, Theresa. 2008. Email Hoaxes. Amsterdam/Philadelphia: John Benjamins.

Ho, Shuyuan Mary, Jeffrey T. Hancock, Cheryl Booth, and Xiuwen Liu. 2016. "Computer-Mediated Deception: Strategies Revealed by Language-Action Cues in Spontaneous Communication.” Journal of Management Information Systems 33 (2): 393-420. https://doi.org/10.1080/07421222.2016.1205924.

Holt, Thomas J., and Danielle C. Graves. 2007. "A Qualitative Analysis of Advance Free Fraud Email Schemes." International Journal of Cyber Criminology 1 (1): 137-54.

Hyland, Ken. 2005. "Stance and Engagement: A Model of Interaction in Academic Discourse." Discourse Studies 7: 173-92. https://doi.org/10.1177\%2F1461445605050365.

Igwe, Chidi. 2007. Taking Back Nigeria from 419: What to Do about the Worldwide E-mail Scam - Advance Fee Fraud. Bloomington: iUniverse.

Jacobs, Pearl, and Linda Schain. 2011. "The Never Ending Attraction of the Ponzi Scheme.” Journal of Comprehensive Research 9: 40-46.

Krige, Detlev. 2012. "Fields of Dreams, Fields of Schemes: Ponzi Finance and Multi-Level Marketing in South Africa." Africa 82 (1): 69-92. https://doi.org/10.1017/S0001972011000738.

Križan, Agata. 2016. "The Language of Appraisal in British Advertisements: The Construal of Attitudinal Judgement." ELOPE 13 (2): 199-220. https://doi.org/10.4312/elope.13.2.199-220.

Leeper Piquero, Nicole, M. Lyn Exum, and Sally S. Simpson. 2005. "Integrating the Desire-For-Control and Rational Choice in a Corporate Crime Context.” Justice Quarterly 22: 252-80. https://doi. org/10.1080/07418820500089034.

Lewis, Mervyn K. 2012. “New Dogs, Old Tricks. Why Do Ponzi Schemes Succeed?” Accounting Forum 36: 294-309.

Luukkonen, Tiina. 2014. “This Will Not Be A Ponzi Scheme': Persuasion in an American Ponzi Scheme.” MA Thesis, Department of Languages, University of Jyväskylä.

Martin, James R., and Peter R. White. 2005. The Language of Evaluation. Appraisal in English. Hampshire and New York: Macmillan.

Moore, Tyler, Jie Han, and Richard Clayton. 2012. "The Postmodern Ponzi Scheme: Empirical Analysis of High-Yield Investment Programs.” In Financial Cryptography and Data Security, edited by Angelos D. Keromytis, 41-56. Berlin, Heidelberg: Springer. https://doi.org/10.1007/978-3-642-32946-3_4.

Newman, Matthew L., James W. Pennebaker, Diane S. Berry, and Jane M. Richards. 2003. "Lying Words: Predicting Deception from Linguistic Styles." Personality and Social Psychology Bulletin 29: 665-75. https://doi.org/10.1177\%2F0146167203029005010.

Ochs, Elinor. 1990. "Cultural Universals in the Acquisition of Language: Keynote Address." Papers and Reports on Child Language Development 29: 1-19. 
Okafor, Godson Okwuchukwu, and Ozioma Perpetua Unachukwu. 2015. "Lying in Mobile Phone Conversations: An Emerging Social Syndrome in Nigeria." Journal of Social Sciences \& Humanities Research 1 (1): 1-7.

Onanuga, Paul. 2017. "Language Use in Nigerian Spam SMSs: A Linguistic Stylistic Analysis." Language Matters 48 (2): 91-116. https://doi.org/10.1080/10228195.2017.1337805.

—. 2020. "When Hip-Hop Meets CMC: Digital Discourse in Nigerian Hip-Hop." Journal of Media \& Cultural Studies 34 (4): 590-600. https://doi.org/10.1080/10304312.2020.1757038.

Onanuga, Paul, and Rotimi Taiwo. 2019. "Multimodality in Selected Nigerian Ponzi Schemes' Narratives." Ekpoma Journal of Languages and Literary Studies 12 (1-2): 327-51.

Palasinski, Marek, and Simon Bignell. 2015. “Seeking Patterns of Digital Deception.” In Encyclopedia of Information Science and Technology, Third Edition, edited by Mehdi Khosrow-Pour, 6446-54. Hershey, PA: Information Science Reference. https://doi.org/10.4018/978-1-4666-5888-2.ch633.

Picornell, Isabel. 2011. “The Rake's Progress: Linguistic Strategies for Deception.” In Proceedings of the International Association of Forensic Linguists' Tenth Biennial Conference, edited by Samuel Tomblin, Nicci MacLeod, Rui Sousa-Silva and Malcolm Coulthard, 153-68. Birmingham, UK: Centre for Forensic Linguistics, Aston University. https://www.forensiclinguistics.net/IAFL10proceedings.pdf.

Rejón-Guardia, Francisco, and Francisco J. Martínez-López. 2014. "Online Advertising Intrusiveness and Consumers' Avoidance Behaviors." In Handbook of Strategic e-Business Management, edited by Francisco J. Martínez-López, 565-86. Berlin, Heidelberg: Springer. https://doi.org/10.1007/978-3642-39747-9_23.

Searle, John R. 1976. “A Classification of Illocutionary Acts.” Language in Society 5 (1): 1-23. https://www. jstor.org/stable/4166848.

Scollon, Ron, and Suzanne Wong Scollon. 1995. Intercultural Communication: A Discourse Approach. Oxford: Blackwell.

Schaffer, Deborah. 2012. "The Language of Scam Spams: Linguistic Features of 'Nigerian Fraud' E-Mails." A Review of General Semantics 69 (2): 157-79. https://www.jstor.org/stable/42579182.

Smith, Andrew. 2009. "Nigerian Scam E-Mails and the Charms of Capital." Cultural Studies 23 (1): 27-47. https://doi.org/10.1080/09502380802016162.

Smith, Daniel Jordan. 2007. A Culture of Corruption: Everyday Deception and Popular Discontent in Nigeria. Princeton, NJ: Princeton University Press.

Sorlin, Sandrine. 2017. “The Pragmatics of Manipulation: Exploiting Im/Politeness Theories." Journal of Pragmatics 121: 132-46. https://doi.org/10.1016/j.pragma.2017.10.002.

Spencer-Oatey, Helen, ed. 2008. Culturally Speaking: Culture, Communication and Politeness Theory. New York: Continuum.

Strohm, Florian, and Roman Klinger. 2018. "An Empirical Analysis of the Role of Amplifiers, Downtoners, and Negations in Emotion Classification in Microblogs." Paper presented at 2018 IEEE 5th International Conference on Data Science and Advanced Analytics (DSAA), Turin, Italy, 673-81. IEEE. https://doi.org/10.1109/DSAA.2018.00087.

Taiwo, Rotimi. 2010. “'The Thumb Tribe': Creativity and Social Change through SMS in Nigeria." California Linguistic Notes XXXV (1): 1-18.

—. 2012. "Discursive Manipulation Strategies in Virtual Scams in Global Contexts." In ComputerMediated Communication across Cultures: InternationaI Interactions in Online Environments, edited by Kirk St. Armant and Sigrid Kelsey, 143-54. Hershey, Pennsylvania: IGI Global. https://doi. org/10.4018/978-1-60960-833-0.ch010.

—. 2016. "Cognitive Verbs and Stance Taking in Nigerian Jobs and Careers Portals Online." Marang: Journal of Language and Literature 27: 1-19.

—. 2017. "Discursive Forms and Functions of Digital Deceptive Communication in Nigerian Online Discourse." In Deception and Deceptive Communication, edited by Innocent Chiluwa, 245-74. New York: Nova Science Publishers.

Tanfa, Denis Yomi. 2006. “Advance Fee Fraud.” PhD diss., University of South Africa, Pretoria.

Tian, Kelly, and Bill Keep. 2002. Customer Fraud and Business Responses: Let the Marketer Beware. Westport CT: Quorum Books. 
Tive, Charles. 2006. 419 Scam: Exploits of the Nigerian Con Man. Bloomington, IN: iUniverse.

Toma, Catalina L., and Jeffrey T. Hancock 2010. "Reading between the Lines: Linguistic Cues to Deception in Online Dating Profiles.” CSCW 2010, February 6-10, 2010, Savannah, Georgia, USA.

Tsikerdekis, Michail, and Zeadally Sherali. 2014. "Online Deception in Social Media." Communications of the ACM 57 (9): 72-80. http://dx.doi.org/10.1145/2629612.

Urowayino, Jeremiah. 2017. "MMM: As the Bubble Bursts." Vanguard, March 23, 2017. https://www. vanguardngr.com $/ 2017 / 03 / \mathrm{mmm}$-bubble-bursts/.

van Dijk, Teun A. 2006. "Ideology and Discourse Analysis.” Journal of Political Ideologies 11 (2): 115-40. https://doi.org/10.1080/13569310600687908.

Vrij, Aldert, Samantha Mann, and Sharon Leal. 2012. "Deception Traits in Psychological Interviewing." Journal of Police and Criminal Psychology 28: 115-26. https://doi.org/10.1007/s11896-013-9125-y.

Walsh James. 1999. "How Ponzi Schemes, Pyramid Frauds Work." Consumers' Research Magazine 82 (6): $10-14$.

Whitty, Monica T., Tom Buchanan, Adam N. Joinson, and Alex Meredith. 2012. "Not All Lies Are Spontaneous: An Examination of Deception across Different Modes of Communication." Journal of the American Society for Information Science and Technology 63 (1): 208-16. https://doi.org/10.1002/ asi.21648.

Woker, T. A. 2003. "If It Sounds Too Good to Be True It Probably Is: Pyramid Schemes and Other Related Frauds." South African Mercantile Law Journal 15 (2): 237-49.

Zahra, Shaker A., Richard L. Priem, and Abdul A. Rasheed. 2007. "Understanding the Causes and Effects of Top Management Fraud." Organizational Dynamics 36 (2): 122-39.

Zhou, Lina, Judee K. Burgoon, Jay F. Nunamaker, and Doug Twitchell. 2004. "Automating LinguisticsBased Cues for Detecting Deception in Text-Based Asynchronous Computer-Mediated Communications." Group Decision and Negotiation 13 (1): 81-106. 